\title{
UNDER AN UNCARING SKY
}

\author{
Ill met by starlight.
}

\section{BY WILLIAM MEIKLE}

$\mathrm{I}$ volunteered for this - our ore would last only ten more years, so somebody had to do something. The flyer they gave me hadn't been upside for 30 years; nobody had. The dimming had seen to that. Too cold, too dark. No point.

I switched on the ore probe and let it run. I had nothing to do for hours except hang there in the sky and try to ignore the stars that now seemed to be falling ever closer, threatening to wrap themselves around me, engulf me and drag me off to the black beyond. I almost didn't hear the beep as the probe finally announced a finding.

The flyer told me I was somewhere in the South Pacific. It looked little different from the spot where I had come upside, but as I descended I saw that the ice here was less compacted. Several darker patches showed. As I got closer, I could see that there were stretches of broken ice and slush. I started to think there might even be open water available. The probe beeped a proximity alert as the flyer hovered ten feet above an island of rock, black against the ice all around.

There was ore here, and a lot of it. The scan showed a seam, some 100 feet deep in the rock. I put the flyer down on the flattest spot I could find and started the drill before I put on a helmet and ventured outside, aware even as I did so that I was probably the first human to walk above ground for three centuries.

The only sound was the steady grinding of drill on rock. My heads-up told me that the strata being drilled were sedimentary on top of schist, the drill currently penetrating rock that was more than two hundred million years old, and going through a million years of sediment a second.

All of which was secondary to the fact that I had just found a cave.

I almost felt at home. The walls were smooth - some weathering process over the millennia was my assumption - and the light from my helmet was bright enough to light my way for 20 yards ahead. The cave floor sloped downwards, and as I proceeded the temperature rose. Fifty yards in, I had to turn off the suit heater. I also got the first indication that this was more than just a simple cave. I found a number imprinted on the wall: SUB-LEVEL 25.

The passageway was man-made.

I found the first corpse seconds later.

I did not look too closely, but judging by the decomposition of the clothing, I guessed that many years had passed since the time of death. I kept going, but I was no longer hopeful that I would meet anyone still alive.

The corridor opened into a wider chamber, an eating area of sorts.

Bodies lay strewn everywhere, lying in mounds or in pairs. Skeletal arms were wrapped around broken necks, skulls showed signs of having been smashed against table and floor. They had killed each other in a frenzied melee.

As I bent to inspect the closest, I saw the cause.

The darkness danced in their eye sockets, a deeper shadow. It was full of stars where the sky had fallen in and got them. The more I looked, the more I saw it; there in the $\rightarrow$ NATURE.COM

Follow Futures: @NatureFutures $f$ go.nature.com/mtoodm shadow where a body hung over an overturned chair, there in the corner under the food processors, but mostly in the eyes, dancing and twinkling, mocking my horror.

I stumbled past more bodies than I could count, searching for a reason, an answer as to what had happened. The empty eyes followed me everywhere I went. There was a door opposite me, and I went through, hoping for some small escape from the terror.

There were no bodies in this part of the system, just long empty corridors, but that somehow only made matters worse. Although I was still safe inside the suit, the air seemed somehow thicker here, more oppressive; a faint trace of blue mist hung in the air. If I were back home, I knew I would be approaching the bionic plant now. Despite the terrors of the eating area above, I was almost eager to visit the working parts of the site, as there might even be something salvageable there, something that would further prolong our own time here in the warren.

I descended a stairwell and walked out into their bionics plant.

Scores of eyes turned and looked at me, reflecting like twinkling stars in my helmet light.

They had once been human, but their skin was pale, almost translucent, their eyes large, like saucers in heads too small to hold them. They scrambled, on all fours, amid a pile of slurry and started to crawl towards me, piteously mewling like hungry kittens. Stars danced in their eyes.

I will not tell of my flight from that place, save to say that I have deleted the coordinates from the systems. If you want the ore, you will have to send out another flyer.

But I would advise against it, for the darkness will come back with them. The sky will fall, and your eyes will fill with stars. The darkness will get inside, and it will consume you, as it did those poor things in the bionics lab ... as it has started to do to me.

It is vast, it is empty, and it does not care. It just does not care.

William Meikle is a Scottish writer, now living in Canada, with 20 novels published in the genre press and more than 300 shortstory credits in 13 countries. 